
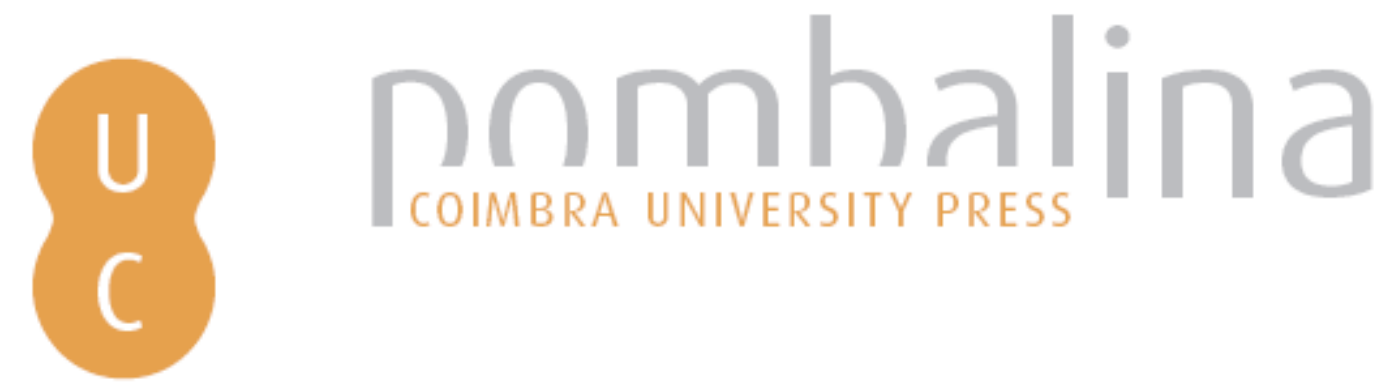

\title{
Wildfire occurrence estimation in Spanish regions based on Land Use-Land Cover interfaces and biophysical variables
}

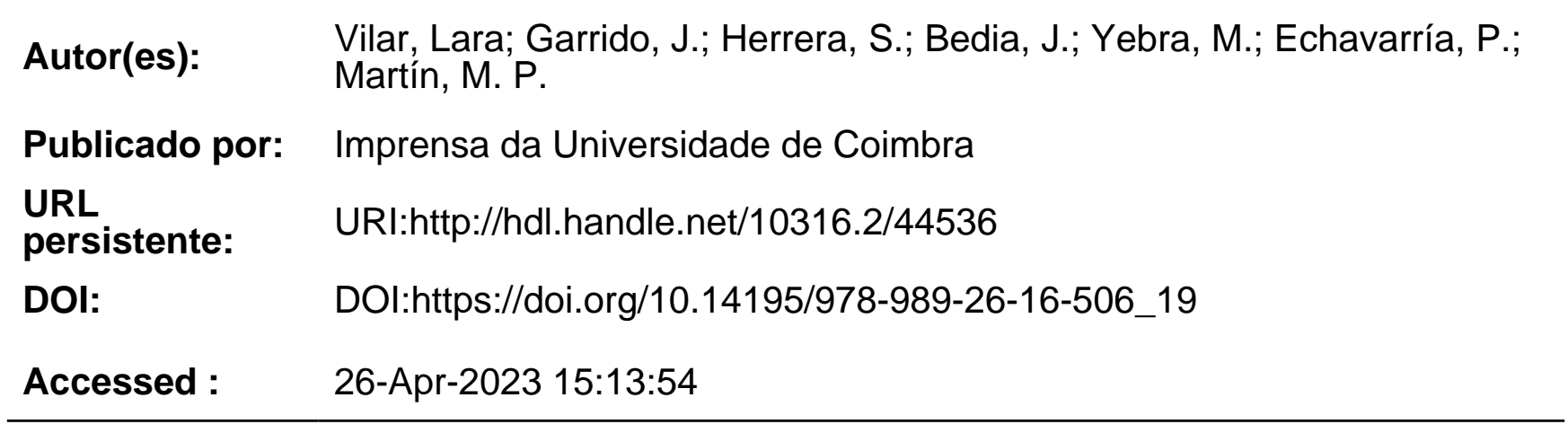

A navegação consulta e descarregamento dos títulos inseridos nas Bibliotecas Digitais UC Digitalis, UC Pombalina e UC Impactum, pressupõem a aceitação plena e sem reservas dos Termos e Condições de Uso destas Bibliotecas Digitais, disponíveis em https://digitalis.uc.pt/pt-pt/termos.

Conforme exposto nos referidos Termos e Condições de Uso, o descarregamento de títulos de acesso restrito requer uma licença válida de autorização devendo o utilizador aceder ao(s) documento(s) a partir de um endereço de IP da instituição detentora da supramencionada licença.

Ao utilizador é apenas permitido o descarregamento para uso pessoal, pelo que o emprego do(s) título(s) descarregado(s) para outro fim, designadamente comercial, carece de autorização do respetivo autor ou editor da obra.

Na medida em que todas as obras da UC Digitalis se encontram protegidas pelo Código do Direito de Autor e Direitos Conexos e demais legislação aplicável, toda a cópia, parcial ou total, deste documento, nos casos em que é legalmente admitida, deverá conter ou fazer-se acompanhar por este aviso.

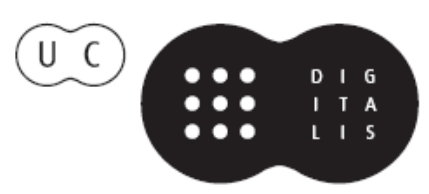




\section{ADVANCES IN}

\section{FOREST FIRE RESEARCH}

\section{8}

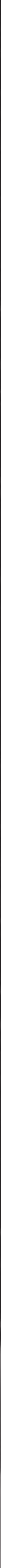




\title{
Wildfire occurrence estimation in Spanish regions based on Land Use- Land Cover interfaces and biophysical variables
}

\author{
Lara Vilar $^{1 *}$, J. Garrido ${ }^{1}$, S. Herrera ${ }^{2}$, J. Bedia ${ }^{2}$, M. Yebra. ${ }^{3,4}$, P. Echavarría ${ }^{1}$, M.P. Martín ${ }^{1}$ \\ 1* Institute of Economics, Geography and Demography, Centre for Human and Social Sciences, \\ Spanish National Research Council (CSIC), Albasanz 26-28, 28037, Madrid, Spain, \\ \{lara.vilar@cchs.csic.es*\} \\ ${ }^{2}$ Meteorology Group. Dpto. De Matemática Aplicada y C.C. University of Cantabria, Avda de los \\ Castros sn, 39005, Santander, Spain \\ ${ }^{3}$ Fenner School of Environment and Society, The Australian National University, Acton, ACT, \\ Australia \\ ${ }^{4}$ Bushfire and Natural Hazards Cooperative Research Centre, Melbourne, Australia.
}

\begin{abstract}
This study aims to estimate wildfire occurrence in two representative Spanish regions with different territorial, social and environmental characteristics as well as fire history; Zamora and Madrid. Land-Use Land Cover (LULC) interfaces derived from ESA Climate Change Iniciative-Land Cover (CCI-LC) 2005 (covering 2003-2007 period at 300m resolution) were used as indirect indicator of socio-economic drivers associated with human-caused wildfire ignition sources. Three general interfaces were used; forestagricultural interface (FAI), grassland-forest interface (GFI) and wildland urban interface (WUI), as well as other more specific ones derived from a disaggregated LULC legend. A set of biophysical variables including orientation, monthly precipitation, temperature (mean, minimum and maximum) as well as live fuel moisture content (FMC) were also considered in the model. Monthly precipitation and temperature were obtained from a regional climate dataset developed for the study sites by the University of Cantabria (Spain) at $1 \mathrm{~km}^{2}$ spatial resolution while FMC were calculated from MODIS images following Yebra et al. (2018) methodology. Orientation was obtained from the Digital Terrain Model at 25m available for Spain at the Spanish National Geographic Institute (CNIG).

Generalized Linear Models (GLMs) were used to obtain four sub-models to estimate wildfire occurrence in the two study regions during the 2000-2010 period. Two models included only LULC interfaces at two different disaggregation levels, and the other two models also included biophysical drivers. Results showed that disaggregated interfaces helped to improve the spatial characterization of probability of occurence. FAI was the LULC general interface that contributed the most to the models. Biophysical drivers had larger contribution to the models than the interfaces but the later still had importance explaining the spatial distribution of the fire occurrence probability. The accuracy of the models improved when biophysical variables were included achieving a sensitivity of $\sim 2 \%$ and omission errors of $\sim 58 \%$ in Zamora and $\sim 6 \%$ and $90 \%$, respectively in Madrid. The results for Madrid were less accurate mainly due to the small number of fire events to fit the models. Future works will deal with modeling in areas with small but of importance number of fires as in this last site. This study indicates that the human component of wildfires represented by LULC interfaces and its disaggregation can be integrated into wildfire occurrence estimation.
\end{abstract}

Keywords: CCI-Land Cover, LULC interfaces, MODIS Hotspots, wildfires

\section{Introduction}

Reported changes in the use of land and in climate are affecting the fire cycle (Pausas and Fernández-Muñoz 2012) increasing the frequency and severity of wildland fires (Moreno et al. 2013) and leading to threats to the ecosystem stability, the provision of services, habitat conservation as well as properties and human lives. Most of these fires are human-caused so an effort is necessary to identify and monitor fire risk associated to human activity. Previous works to predict wildfire occurrence have considered different types of factors that represent the human activities that can lead to the ignition of 
a fire i.e. roads, electric lines, population, natural protected areas (Martínez et al. 2009) (Rodrigues 2014) (Vilar et al. 2016b). Among all the considered factors, the contact areas between the forest and other land cover (the so-called interfaces) have been also included because of the high implication for the security of the people living close to these areas as in the Wildland Urban Interface (WUI). However, in these contact areas human activities cannot only suffer the effects but also to lead to fire ignitions either by accident, negligence or deliberate actions (pasture or agricultural burnings, recreational activities close to urban areas, etc.). Consequently, Land Use Land Cover (LULC) interfaces can be considered as a proxy to human activities associated to potential sources of wildfires ignition (Gallardo et al. 2015) (Vilar et al. 2016a). In this work we consider different LULC interfaces at various thematic disaggregation levels in combination with other biophysical parameters associated to wildfire ignition risk, to estimate fire occurrence at a regional scale. The study sites are two Spanish provinces, Zamora and Madrid, because of their differences in terms of territorial characteristics, LULC and fire history. Generalized Linear Models (GLMs) were applied for the period 2000-2010 and four sub-models at $1 \mathrm{~km}^{2}$ grid cell resolution were calculated for each province by using (1) LULC interfaces (general and specific) and (2) a combination of LULC interfaces and biophysical variables (precipitation, temperature and Fuel Moisture Content-FMC-).

\section{Methods}

\subsection{Study sites}

The study sites are two Spanish provinces, Zamora and Madrid (Figure 1). The two regions are quite similar in size (Zamora area is $\sim 10,500 \mathrm{~km}^{2}$ and Madrid $\sim 8,400 \mathrm{~km}^{2}$ ) and are dominated by Mediterranean continental climate (mean temperature $12-14^{\circ} \mathrm{C}$ and $400-1000 \mathrm{~mm}$ annual precipitation (AEMET 2011)). However, both regions have substantial differences in population density (17 hab $/ \mathrm{km}^{2}$ in Zamora and $800 \mathrm{hab} / \mathrm{km}^{2}$ in Madrid) (INE 2018). Regarding natural vegetation forest, mainly evergreen occupy the $25 \%$ of the total area in both provinces. Important zones are covered by shrublands in Zamora, and only less than the $2 \%$ is covered by grassland, while Madrid is mainly dominate by mixed shrubland-trees, deciduous forest and grasslands, with the latest representing approximately a 14\% of the surface (CCI-LC 2010).

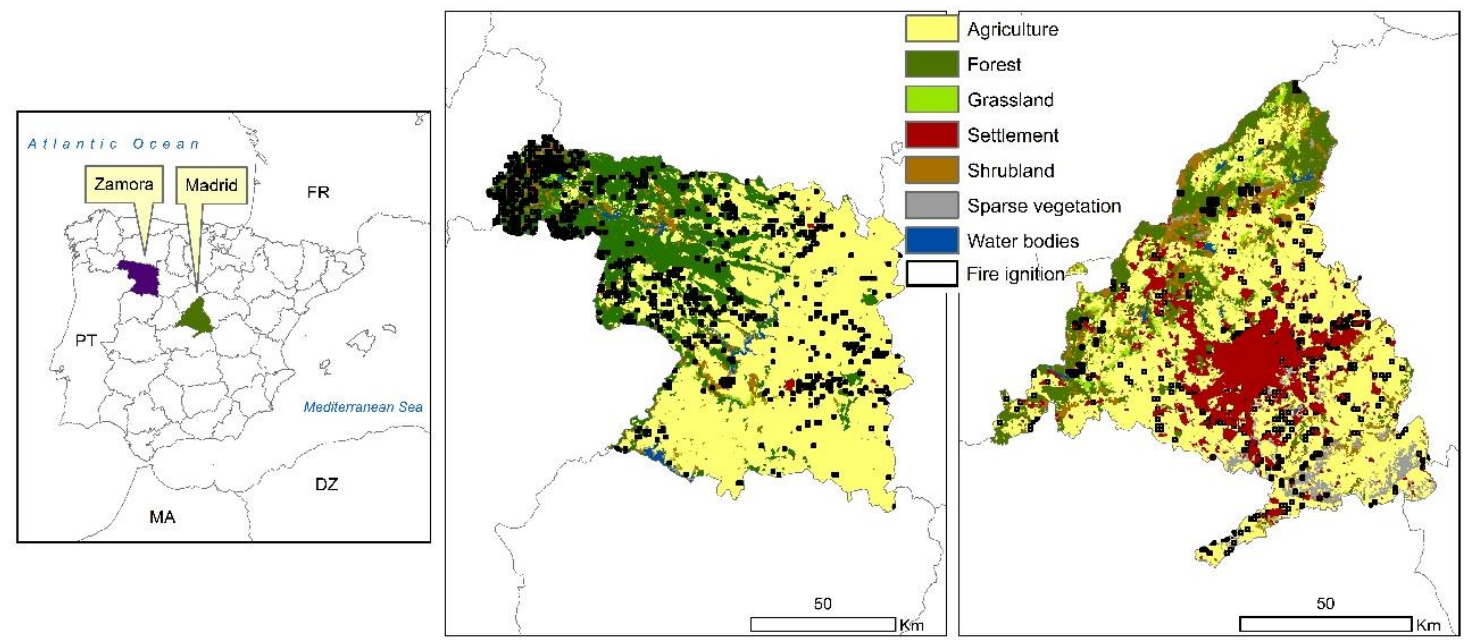

Figure 1 - Location of the study sites and their corresponding reclassified Land Cover categories from ESA Climate Change Iniciative-Land Cover (CCI-LC) and obtained ignition points 2001-2010 (MODIS Burned Area MCD64A1 and MODIS Hotspots products combination)

Agricultural areas cover $\sim 64 \%$ and $\sim 40 \%$ of the territory in Zamora and Madrid respectively. Urban areas represent $\sim 9 \%$ of the territory in Madrid while are really scarce in Zamora $(<1 \%)$. Concerning wildfires 5,200 events happened in Zamora between 2001 and 2010 period, burning 14,000 ha. 1,000 fire events affected 25,000 ha in Madrid. Deliberately caused wildfires are more than $75 \%$ in Zamora 
while in Madrid accidents cause the $22 \%$ of the total wildfires being $~ 50 \%$ classified as unknown causes (Cubo María et al. 2012).

\subsection{Data}

\subsubsection{Fire data}

Fire data used for this work was the result of combining two data sources, (1) MODIS Terra and Aqua Burned Area (BA) MCD64A1 product, which is a global and monthly gridded $500 \mathrm{~m}$ resolution product (Giglio and Justice 2015) and (2) MODIS Hotspots (HS) from MCD14DL and the Visible Infrared Imaging Radiometer Suite (VIIIRS) 375 m (VNP14IMGTDL_NRT) (Giglio L et al. 2003). BA was downloaded from LP-DAAC NASA Land Products and Services (https://lpdaac.usgs.gov/dataset_discovery/modis/modis_products_table/mcd64a1_v006) and HS from Active Fire Data (https://firms.modaps.eosdis.nasa.gov/) for the period 2000-2010. The BA polygons with less than $50 \mathrm{~m}$ distance between them were assumed to be the same fire event and therefore were grouped. Afterwards, the pixel with the earliest date was selected from the group and considered the ignition point. Spatial coincidence between the HS and the BA was checked to confirm the location of the fire ignition point. All the HS detected at the same date and less than $1,500 \mathrm{~m}$ distance from the BA polygons were considered to belong to the same fire (Hantson et al. 2013; Vilar et al. 2015). Also, groups of HS with no BA associated but with a distance less than $1,500 \mathrm{~m}$ among them were assumed to be another fire event. Afterwards those selected BA pixel or HS were placed within the $1 \mathrm{~km}^{2}$ cell grid of reference. The response variable was finally established as the presence or absence of fires in the period 2000-2010 in each $1 \mathrm{~km}^{2}$ grid cell.

\subsubsection{Independent variables of the model}

Several LULC Interfaces and biophysical variables were considered independent vatiables of the model (Table 2). LULC interfaces were derived from ESA CCI LC products (Defourny et al. 2016). The main source of input Earth Observation (EO) data for the global LC maps is the full archive (20032012) of MERIS instrument (Bontemps et al. 2015) at $300 \mathrm{~m}$ resolution. To obtain the LULC interfaces the original CCI-LC 2005 epoch (2003-2007 period) legend was reclassified as showed in Table 2. The three general interfaces were defined as follows forest (class 2)- agricultural (class 1) interface (FAI), forest (class 2)- grassland (class 3) interface (FGI) and wildland (class 2)-urban (class 5) interface (WUI). Other 23 specific LULC interfaces were obtained (6 urban, 12 agricultural and five grasslands types). LULC interfaces were spatially defined as the contact pixels among uses that formed each interface type; then, they were overlaid with the $1 \mathrm{~km}^{2}$ cell grid and thus the density value of each interface in each cell was calculated, obtaining the LULC independent variables by $1 \mathrm{~km}^{2}$.

Table 1 - CCI-LC legend reclassification to define LULC interfaces

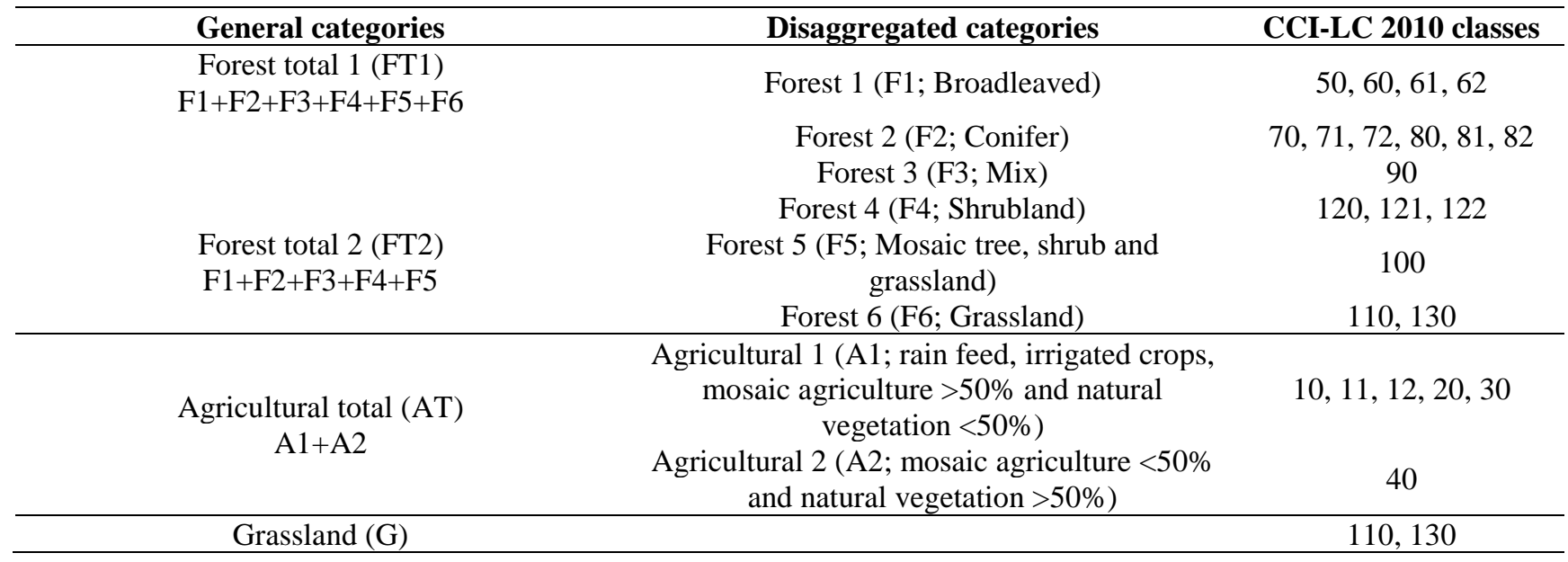


Forest total 1 (FT1) was the sum of all forest categories while Forest total 2 (FT2) excluded forest grassland (F6). Agricultural total (AT) was the sum of A1 and A2. Figure 32 shows the spatial location of the general LULC interfaces.

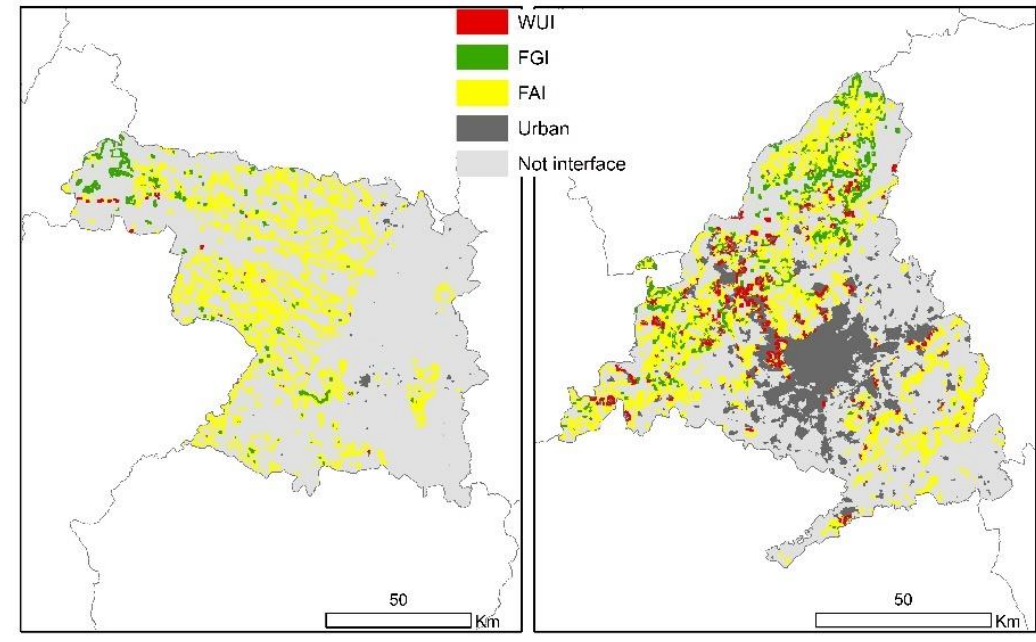

Figure 2 - LULC Interfaces Forest-Grassland Interface (FGI), Forest-Agriculture Interface (FAI) and WildlandUrban Interface (WUI) at 1km2 grid cell resolution for Zamora (left) and Madrid (right)

As biophysical parameters were considered orientation, maximum, minimum and mean temperature, accumulated precipitation and live Fuel Moisture Content (FMC). Regarding the meteorological variables (maximum, minimum and mean temperature, and accumulated precipitation) used for this study, they have been built based on a quality controlled weather stations network belonging to the Spanish Meteorology Agency (AEMET). A two-step regression kriging (Hengl et al. 2007) interpolation method has been applied to the monthly values. First, a regression model was defined for each region considering as predictors several orographic variables including elevation, distance to coastline and topographic blocking effects (Bedia et al. 2013) to interpolate the observations to the high-resolution grid of $1 \mathrm{~km}^{2}$ spatial resolution. Then, the monthly residuals obtained from the regression model were interpolated to the target resolution using Ordinary Kriging. Finally, the interpolated values were obtained by combining both interpolated values using an additive and multiplicative functions for temperatures and precipitation, respectively. As a result, the weatherrelated biophysical parameters (Table 2) were defined as the climatologies for the period considered in the analysis (2000-2010).

Live FMC was obtained using a physically-based retrieval model and MODIS reflectance data (MCD43A4 Collection 6) using radiative transfer model Look-Up Table inversion (Yebra et al. 2018).

Table 2 - Independent variables of the model

\begin{tabular}{|c|c|c|c|}
\hline Variable type & Variable & Description & Abbreviation \\
\hline \multirow[t]{4}{*}{ Biophysical } & $\begin{array}{l}\text { Mean accumulated } \\
\text { precipitation }\end{array}$ & $\begin{array}{l}\text { Interpolated monthly } \\
\text { accumulated precipitation } \\
(\mathrm{mm}) . \text { Mean of 2000-2010 }\end{array}$ & pr_m \\
\hline & $\begin{array}{l}\text { Mean monthly } \\
\text { maximum, } \\
\text { minimum and } \\
\text { mean temperature }\end{array}$ & $\begin{array}{l}\text { Interpolated monthly } \\
\text { maximum, minimum and } \\
\text { mean temperature }\left({ }^{\circ} \mathrm{C}\right) \text {. } \\
\text { Mean of } 2000-2010\end{array}$ & $\begin{array}{l}\text { tmax_m } \\
\text { tmin_m } \\
\text { tas_m }\end{array}$ \\
\hline & $\begin{array}{c}\text { Live Fuel Moisture } \\
\text { Content }\end{array}$ & Mean of $2000-2010$ & LFMC_m \\
\hline & Orientation & & or \\
\hline $\begin{array}{l}\text { LULC main } \\
\text { interfaces }\end{array}$ & $\begin{array}{c}\text { Forest Agricultural } \\
\text { Interface }\end{array}$ & $\begin{array}{c}\text { Agricultural1+Agricultural } 2 \\
\text { || Forest total } 1\end{array}$ & FAI \\
\hline
\end{tabular}




\begin{tabular}{|c|c|c|c|}
\hline 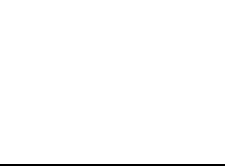 & $\begin{array}{l}\text { Forest Grassland } \\
\text { Interface } \\
\text { Wildland Urban } \\
\text { Interface }\end{array}$ & $\begin{array}{c}\text { Grassland \| Forest total } 2 \\
\text { Urban } \| \text { Forest total } 1\end{array}$ & $\begin{array}{l}\text { FGI } \\
\text { WUI }\end{array}$ \\
\hline $\begin{array}{c}\text { LULC specific } \\
\text { interfaces }\end{array}$ & & $\begin{array}{c}\text { Urban || Forest } 1 \\
\text { Urban \|| Forest } 2 \\
\text { Urban \|| Forest } 3 \\
\text { Urban \|| Forest } 4 \\
\text { Urban \|| Forest } 5 \\
\text { Urban \|| Forest } 6 \\
\text { Agricultural } 1 \text { || Forest } 1 \\
\text { Agricultural } 1 \text { || Forest } 2 \\
\text { Agricultural } 1 \text { || Forest } 3 \\
\text { Agricultural } 1 \text { || Forest } 4 \\
\text { Agricultural } 1 \text { || Forest } 5 \\
\text { Agricultural } 1 \text { || Forest } 6 \\
\text { Agricultural } 2 \text { || Forest } 1 \\
\text { Agricultural } 2 \text { || Forest } 2 \\
\text { Agricultural } 2 \text { || Forest } 3 \\
\text { Agricultural } 2 \text { || Forest } 4 \\
\text { Agricultural } 2 \text { || Forest } 5 \\
\text { Agricultural } 2 \text { || Forest } 6 \\
\text { Grassland || Forest } 1 \\
\text { Grassland || Forest } 2 \\
\text { Grassland || Forest } 3 \\
\text { Grassland }|| \text { Forest } 4 \\
\text { Grassland }|| \text { Forest } 5 \\
\end{array}$ & $\begin{array}{l}\text { U-F1 } \\
\text { U-F2 } \\
\text { U-F3 } \\
\text { U-F4 } \\
\text { U-F5 } \\
\text { U-F6 } \\
\text { A1-F1 } \\
\text { A1-F2 } \\
\text { A1-F3 } \\
\text { A1-F4 } \\
\text { A1-F5 } \\
\text { A1-F6 } \\
\text { A2-F1 } \\
\text { A2-F2 } \\
\text { A2-F3 } \\
\text { A2-F4 } \\
\text { A2-F5 } \\
\text { A2-F6 } \\
\text { G-F1 } \\
\text { G-F2 } \\
\text { G-F3 } \\
\text { G-F4 } \\
\text { G-F5 }\end{array}$ \\
\hline
\end{tabular}

\subsection{Statistical analysis: Generalized Linear Models (GLMs)}

Wildfire occurrence was estimated using Generalized Linear Models (GLMs). GLMs are extensions of linear regression models that support dependent variables with non-normal distributions, such as binomials (Guisan et al. 2002). Fire events are a rare event and therefore the number of cells with fire absence is highly superior to the cells with fire presence. A random sample of the absencefire cells was selected as model input to retain enough covariate information on the non-ignitions for modelling as in Preisler (2004). This introduces a deterministic offset term of $-\log \left(\pi_{\mathrm{xyt}}\right)$ that does not bias the analysis (Vilar et al. 2010). $\pi_{\mathrm{xyt}}$ denotes the response-specific sampling rate. When $\pi_{\mathrm{xyt}}=1, \pi_{\mathrm{xyt}}$ is also 1 , and when $\pi_{\mathrm{xyt}}=0, \pi_{\mathrm{xyt}}=\pi$. In this work a sample of $10 \%$ (Zamora) and $5 \%$ (Madrid) of the zero-fire cells was selected. See Preisler et al. for further details (2004). The resulting dataset was randomly divided into two groups, $75 \%$ for model calibration and $25 \%$ for validation. The lowest Akaike's Information Criterion (AIC) value was use to select the best model. As regression models assume uncorrelated independent variables, a multicollinearity analysis was performed before running GLM using the Spearman correlation among variables and by Variance Inflation Factor (VIF). VIF can distinguish the degree of multicollinearity when variables are not centred (Freund et al. 2003). Spearman correlations higher than 0.7 and/or VIF higher than 10 (Hair et al. 1995) indicated multicollinearity and affected independent variables were not included in the analysis.

\section{Results}

Four sub-models to estimate wildfire occurrence were obtained for each province (Table 4 and Table 5). Exploratory analysis showed high Spearman correlations between tmin_m and tmax_m (0.77) and between tas_m with tmax_m and tmin_m ( 0.9) with VIF>100 in Zamora. So for multicollinearity problems tmin_m and tas_m were not included into the analysis. 
Table 3 - Estimated coefficients and significances (Wald test) for each of the GLM predictors for Zamora

\begin{tabular}{|c|c|c|c|c|}
\hline & \multicolumn{2}{|c|}{ LULC } & \multicolumn{2}{|c|}{ LULC + Biophysical } \\
\hline & \multicolumn{2}{|c|}{ LULC general } & \multicolumn{2}{|c|}{ LULC general } \\
\hline Predictor & Estimated coefficient & Probability & Estimated coefficient & Probability \\
\hline (Intercept) & -2.1127 & $<2 \mathrm{e}-16 * * *$ & -6.3841 & $1.62 \mathrm{e}-06 * * *$ \\
\hline FAI & 0.3815 & $0.0307 *$ & 0.7239 & $0.000153 * * *$ \\
\hline WUI & 9.2816 & $0.0408 *$ & - & - \\
\hline FGI & 2.5393 & $9.65 \mathrm{e}-08 * * *$ & - & - \\
\hline tmax_m & - & - & 0.1058 & 0.100256 \\
\hline pr_m & - & - & 0.0433 & $<2 \mathrm{e}-16 * * *$ \\
\hline \multirow[t]{2}{*}{ LFMC_m } & - & - & -0.0291 & $0.000115 * * *$ \\
\hline & \multicolumn{2}{|c|}{ LULC specific } & \multicolumn{2}{|c|}{ LULC specific } \\
\hline (Intercept) & -2.0403 & $<2 \mathrm{e}-16 * * *$ & -7.6508 & $3.49 \mathrm{e}-08 * * *$ \\
\hline A1-F1 & 3.02733 & 0.074423 & enter & - \\
\hline A1-F2 & 2.76241 & $0.003724 * *$ & 1.5750 & 0.1353 \\
\hline A1-F3 & & & 16.4596 & 0.2393 \\
\hline A1-F5 & - & - & 1.2283 & $0.0018 * *$ \\
\hline A2-F1 & 28.13043 & 0.26208 & 54.2354 & 0.1163 \\
\hline A2-F2 & & & -3.7303 & $0.0092 * *$ \\
\hline A2-F4 & - & - & 1.7752 & 0.0627 \\
\hline A2-F5 & 4.4464 & $0.00021 * * *$ & 2.0049 & 0.1270 \\
\hline A2-F6 & -2.6657 & $0.02520 *$ & -3.0915 & $0.0182 *$ \\
\hline U-F1 & & & -76.6902 & 0.2126 \\
\hline U-F3 & & & -5.6318 & 0.0538 . \\
\hline U-F6 & 64.5968 & 0.1569 & - & - \\
\hline G-F2 & 2.5017 & 0.05652 . & - & - \\
\hline G-F4 & 7.6999 & $0.00015 * * *$ & - & - \\
\hline tmax_m & - & - & 0.17048 & $0.0110 *$ \\
\hline pr_m & - & - & 0.04573 & $<2 \mathrm{e}-16 * * *$ \\
\hline LFMC_m & - & - & -0.02834 & $0.00023 * * *$ \\
\hline
\end{tabular}

In Zamora province, the model using as independent variables only general LULC interfaces (FAI, FGI and WUI) showed that the three of them were significant, however where the biophysical variables were also included the only significant LULC was the FAI along with the mean precipitation and the live FMC. In those models that included all 23 specific LULC interfaces, the ones that contributed to the model were the Agricultural (with no natural vegetation, A1)-Conifer forest (F2), Mosaic agriculture (A2)- Mosaic forest (F5), Mosaic agriculture (A2)-Forest grassland (F6) and GrasslandShrub (F4) interface. Both mean precipitation and live FMC were significant when the biophysical variables were included in the model. A2-F6 was also contributing to the model as well as two more specific agricultural-forest related interfaces. The global accuracy of the models improved when the biophysical variables were included with a sensitivity a omission error of $42.78 \%$ and $57.22 \%$ and $41.18 \%$ and $58.82 \%$ in the LULC general and specific model, respectively.

Table 4 - Estimated coefficients and significances (Wald test) for each of the GLM predictors for Madrid

\begin{tabular}{lrrrr}
\hline & \multicolumn{2}{c}{ LULC } & \multicolumn{2}{c}{ LULC + Biophysical } \\
\hline & \multicolumn{3}{c}{ LULC general } & \multicolumn{2}{c}{ LULC general } \\
\hline Predictor & Estimated coefficient & Probability & Estimated coefficient & Probability \\
(Intercept) & -1.3870 & $<2 \mathrm{e}-16 * * *$ & -0.0081 & 0.9850 \\
FAI & -2.1279 & $4.62 \mathrm{e}-12 * * *$ & -1.8267 & $1.65 \mathrm{e}-08 * * *$ \\
WUI & - & - & & - \\
FGI & - & - & & $0.0011^{* *}$ \\
pr & - & - & -0.0350 & - \\
\hline
\end{tabular}




\begin{tabular}{|c|c|c|c|c|}
\hline & \multicolumn{2}{|c|}{ LULC specific } & \multicolumn{2}{|c|}{ LULC specific } \\
\hline (Intercept) & -1.4321 & $<2 \mathrm{e}-16 * * *$ & 0.0380 & 0.9329 \\
\hline A1-F3 & -21.2314 & 0.1652 & -19.3975 & 0.1682 \\
\hline A1-F5 & -3.5485 & $0.0191^{*}$ & -3.4152 & $0.0272 *$ \\
\hline A1-F6 & -1.9583 & $0.02594 * *$ & -2.422 & $0.0019 * *$ \\
\hline A2-F3 & 36.6788 & 0.3786 & 33.1694 & 0.3575 \\
\hline A2-F5 & -3.5859 & $0.0014 *$ & -3.0695 & $0.0064 * *$ \\
\hline U-F2 & 4.7141 & 0.1728 & 6.0985 & 0.1009 \\
\hline G-F1 & -28.0549 & 0.2770 & -28.9154 & 0.2360 \\
\hline G-F2 & & 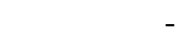 & 6.2943 & $0.0479 *$ \\
\hline G-F5 & -8.8926 & $0.0001 * * *$ & -9.8587 & $0.0001 * * *$ \\
\hline $\mathrm{pr}$ & & - & -0.0382 & $0.0006 * * *$ \\
\hline
\end{tabular}

In Madrid the model with the general LULC interfaces showed FAI was significant and with negative sign. When the biophysical variables were added, the mean precipitation also contributed to the model. Regarding the models that included the specific LULC interfaces the significant variables were the Agricultural (with no natural vegetation, A1)- Forest Mosaic forest (F5) and Forest grassland (F6), and Grassland- Mosaic forest (F5) (negative trend). When biophysical variables were included, mean precipitation was significant as well as three agricultural-related LULC specific interfaces (A1F5, A1F6, A2F5), G-F2 and G-F5. Similarly to Zamora, the global accuracy of the models also improved in Madrid when the biophysical variables were included with a sensitivity of $\sim 6 \%$ and a large omission error of $\sim 90 \%$. However, the general fit of the model was not satisfactory for this site.

\section{Discussion and conclusions}

LULC interfaces have been used as predictor factors to estimate wildfire occurrence in previous works (Syphard et al. 2007); (Padilla and Vega-García 2011); (Vilar et al. 2016b); (Martínez et al. 2009). In this work include LULC disaggregated interfaces were included to consider different forest types regarding tree species (conifer, deciduous, mixed) and different vegetation formations (shrubs and pastures). Two very different Spanish provinces (Zamora and Madrid) have been analyzed with the aim to obtain predictive wildfire models that gathered those territorial and fire-related differences. The inclusion of the biophysical variables allowed to quantify the improvement on the predictive ability of the proposed models in comparison to models only calibrated with LULC.

Biophysical factors contributed the most in both sites. Mean precipitation and LFMC were the stronger contributors in Zamora while precipitation in Madrid. Regarding the LULC interfaces, agricultural-forest related interfaces explained fire occurrence in Zamora with the expected trends (positive), coincident with Rodrigues et al. (2014). The authors used Geographic Weighted Regression (GWR) model for the estimation of fire occurrence probability in Spain and FAI interface also showed an important contribution in Zamora. Also, FGI contributed to the general model, possibly related fires associated with accidents or negligences derived from traditional agricultural practices as pasture burning. In Madrid, none of the specific WUI related interfaces contributed to the model and most of the variables had a negative trend, contrary as expected about fire ignition in this region (Vilar et al. 2016b).

In general, the models performed better in Zamora than in Madrid. We hypothesize that the spatial distribution of the response variable might be influencing in this result as MODIS is mainly detecting the agricultural fires but not the forest fires due to the small area that these fires usually have in this region where firefighting is quite effective in extinguishing the fires in their earlier phases.

The use of indicators of human-related ignition potential is a key issue in fire risk estimation in European Mediterranean areas where a high percentage of fires are due to human causes. As proven in this work and also demonstrate by other authors, LULC interfaces indirectly represent human 
activities associated with fire ignition. This information can be obtained from Land Cover (LC) maps globally available at appropriate management scales as is the case for the CCI-LC. This availablility of global LC maps will allow applying the proposed methodology to other study sites and temporal periods. The combination of specific LULC interfaces along with the biophysical variables might help to obtain a more detailed wildfire occurrence explanation at a global scale too.

\section{References}

AEMET (2011) 'Atlas Climático Ibérico.' (Ministerio de Agricultura, Alimentación y Medio Ambiente: Spain)

Bedia, J, Herrera, S, Gutiérrez, JM (2013) Dangers of using global bioclimatic datasets for ecological niche modeling. Limitations for future climate projections. Global and Planetary Change 107, 112.

Bontemps, S, Boettcher, M, Brockmann, C, Kirches, G, Lamarche, C, Radoux, J, Santoro, M, Van Bogaert, E, Wegmüller, U, Herold, M, Achard, F, Ramoino, F, Arino, O, Defourny, P (2015) 'Multiyear global land cover mapping at $300 \mathrm{~m}$ and characterization for climate modelling: achievements of the land cover component of the ESA Climate Change Initiative, 36th International Symposium on Remote Sensing of Environment.' 11-15 May 2015. (The International Archives of the Photogrammetry, Remote Sensing and Spatial Information Sciences: Berlin, Germany)

Cubo María, JE, Enríquez, E, Gallar Pérez-Pastor, JJ, Jemes Díaz, V, López García, M, Mateo Díez, ML, Muñoz Correal, A, Parra Orgaz, PJ (2012) Los Incendios Forestales en España. Decenio 20012010. Madrid.

Defourny, P, Kirches, G, Brockmann, C, Boettcher, M, Peters, M, Bontemps, S, Lamarche, C, Schlerf, M, M., S (2016) Land Cover CCI: Product User Guide Version 2. UCL-Geomatics, Louvain-laNeuve, Belgium.

Freund, RJ, Littell, RC, Creighton, L (2003) 'Regression Using JMP.' Cary, NC: SAS Institute, Inc. )

Gallardo, M, Gómez, I, Vilar, L, Martínez-Vega, J, Martín, MP (2015) Impacts of future land use/land cover on wildfire occurrence in the Madrid region (Spain). Regional Environmental Change 16, 1047-1061.

Giglio L, Kendall JD, R, M (2003) A multi-year active fire dataset for the tropics derived from the TRMM VIRS. Internarional Journal of Remote Sensing 24, 4505-4525.

Giglio, L, Justice, C, 2015. MCD64A1 MODIS/Terra+Aqua Burned Area Monthly L3 Global 500m SIN Grid V006

Guisan, A, Edwards, TC, Hastie, T (2002) Generalized linear and generalized additive models in studies of species distributions: setting the scene. Ecological Modelling 157, 89-100.

Hair, JFJ, Anderson, RE, Tatham, RL, Black, WC (1995) 'Multivariate Data Analysis.' (Macmillan Publishing Company: New York)

Hantson, S, Padilla, M, Corti, D, Chuvieco, E (2013) Strengths and weaknesses of MODIS hotspots to characterize global fire occurrence. Remote Sensing of Environment 131, 152-159.

Hengl, T, Heuvelink, G, Rossiter, D (2007) About regression-kriging: from equations to case studies. Computers and Geosciences 33, 1301-1315.

INE (2018) 'Cifras de población y censos demográficos. http://www.ine.es/.' Available at http://www.ine.es/dyngs/INEbase/es/categoria.htm?c=Estadistica_P\&cid=1254735572981

Martínez, J, Vega-García, C, Chuvieco, E (2009) Human-caused wildfire risk rating for prevention planning in Spain. Journal of Environmental Management 90, 1241-1252.

Moreno, JM, Vallejo, R, Chuevico, E (2013) Current Fire Regimes, Impacts and the Likely Changes - VI: Euro Mediterranean. In 'Vegetation Fires and Global Change - Challenges for Concerted 
International Action A White Paper directed to the United Nations and International Organizations.' (Ed. JG Goldammer.) (Global Fire Monitoring Center (GFMC): Kessel Publishing House)

Padilla, M, Vega-García, C (2011) On the comparative importance of fire danger rating indices and their integration with spatial and temporal variables for predicting daily human-caused fire occurrences in Spain. International Journal of Wildland Fire 20, 46-58.

Pausas, JG, Fernández-Muñoz, S (2012) Fire regime changes in the Western Mediterranean Basin: from fuel-limited to drought-driven fire regime. Climatic Change 110, 215-226.

Preisler, HK, Brillinger, DR, Burgan, RE, Benoit, JW (2004) Probability bases models for estimation of wildfire risk. International Journal of Wildland Fire 13, 133-142.

Rodrigues, M, de la Riva, J., Fotheringham, S. (2014) Modeling the spatial variation of the explanatory factors of human-caused wildfires in Spain using geographically weighted logistic regression. Applied Geography 48, 52-63.

Syphard, AD, Radeloff, VC, Keeley, JE, Hawbaker, TJ, Clayton, MK, Stewart, SI, Hammer, RB (2007) Human influence in California Fire regimes. Ecological Applications 17, 1388-1402.

Vilar, L, Camia, A, San-Miguel-Ayanz, J (2015) A comparison of remote sensing products and forest fire statistics for improving fire information in Mediterranean Europe. European Journal of Remote Sensing 48, 345-364.

Vilar, L, Camia, A, San-Miguel-Ayanz, J, Martín, MP (2016a) Modeling temporal changes in humancaused wildfires in Mediterranean Europe based on Land Use-Land Cover interfaces. Forest Ecology and Management 378, 68-78.

Vilar, L, Gómez, I, Martínez-Vega, J, Echavarría, P, Riaño, D, Martín, MP (2016b) Multitemporal Modelling of Socio-Economic Wildfire Drivers in Central Spain between the 1980s and the 2000s: Comparing Generalized Linear Models to Machine Learning Algorithms. PLoS ONE 11, e0161344.

Vilar, L, Woolford, DG, Martell, DL, Martín, MP (2010) A model for predicting human-caused wildfire occurrence in the region of Madrid, Spain. International Journal of Wildland Fire 19, 325337.

Yebra, M, Quan, X, Riaño, D, Rozas Larraondo, P, van Dijk, AIJM, Cary, GJ (2018) A fuel moisture content and flammability monitoring methodology for continental Australia based on optical remote sensing. Remote Sensing of Environment 212, 260-272. 